\title{
Evaluation of Prognostic Significance of the International Staging System According to Glomerular Filtration Rate in Newly Diagnosed Multiple Myeloma Patients Eligible for Autologous Stem Cell Transplantation
}

\author{
Otolog Kök Hücre Transplantasyonuna Uygun Yeni Tanı Konmuş Multipl Myelomlu \\ Hastalarda Glomerüler Filtrasyon Hızına Göre Uluslararası Evreleme Sisteminin Prognostik \\ Öneminin Değerlendirilmesi
}

(D) Rafiye Çiftçiler, (D) Hakan Göker, (D) Haluk Demiroğlu, (D) ibrahim Celalettin Haznedaroğlu, (D) Nilgün Sayınalp, (D) Salih Aksu,
(D) Osman Özcebe, (D) Yahya Büyükaşık Hacettepe University Faculty of Medicine, Department of Hematology, Ankara, Turkey

\section{Abstract}

Objective: The prognosis of multiple myeloma (MM) patients is highly heterogeneous. The aim of this study is to determine the impact of patients' renal functions on the prognostic performance of the International Staging System (ISS). In addition, we aimed to evaluate the results of survival of patients with ISS stages and normal renal functions and those with ISS stages and abnormal renal functions with this study.

Materials and Methods: Two hundred and four patients with newly diagnosed MM who received an autologous stem cell transplantation after induction chemotherapy in our tertiary care center between the years of 2001 and 2018 were evaluated.

Results: There were $153(75 \%)$ MM patients who had a glomerular filtration rate (GFR) of $\geq 60 \mathrm{~mL} / \mathrm{min}$ and 51 (25\%) MM patients who had GFR of $<60 \mathrm{~mL} / \mathrm{min}$ at the time of diagnosis in this study. There was a strong correlation between ISS stage and GFR. The ISS stages were higher in patients who had GFR of $<60 \mathrm{~mL} / \mathrm{min}$ than patients who had GFR of $\geq 60 \mathrm{~mL} / \mathrm{min}(\mathrm{p}<0.001)$. Patients with GFR of $<60 \mathrm{~mL} / \mathrm{min}$ were significantly more prevalent in the ISS III group than ISS I and II ( $p<0.001)$.

Conclusion: This study showed that the ISS provides significant prognostic information in MM patients with GFR of $\geq 60 \mathrm{~mL} / \mathrm{min}$ at diagnosis. However, in patients with impaired renal function at the time of diagnosis, B2-microglobulin may not be a good prognostic indicator since it may be affected by renal dysfunction as well as tumor burden.

Keywords: Multiple myeloma, B2-microglobulin, International Staging System

\begin{abstract}
Öz
Amaç: Multipl miyelom (MM) hastalarının prognozu oldukça heterojendir. Bu çalışmanın amacı, hastaların böbrek fonksiyonlarının Uluslararası Evreleme Sistemi'nin (ISS) prognostik performansı üzerindeki etkisini belirlemektir. Ayrıca bu çalışma ile ISS evreli ve böbrek fonksiyonları normal ve anormal olan hastaların ISS evresine göre sağkalım sonuçlarını değerlendirmeyi amaçladık.
\end{abstract}

Gereç ve Yöntemler: 2001-2018 yılları arasında üçüncü basamak merkezimizde indüksiyon kemoterapisi sonrası otolog kök hücre nakli yapılan yeni tanı konmuş MM'li 244 hasta değerlendirildi.

Bulgular: Tanı anında glomerüler filtrasyon hızı (GFR) $\geq 60 \mathrm{~mL} / \mathrm{dak}$ olan 153 (\%75) MM hastası ve GFR'si $<60 \mathrm{~mL} /$ dak olan 51 (\%25) MM hastası vardı. ISS evresi ile GFR arasında güçlü bir ilişki vardı. ISS evreleri, GFR değeri $<60 \mathrm{~mL} /$ dak olan hastalarda GFR'si $\geq 60 \mathrm{~mL} /$ dak olan hastalara göre daha yüksekti $(p<0,001)$. GFR değeri $<60 \mathrm{~mL} /$ dak olan hasta sayıSı, ISS 3 grubunda ISS 1 ve 2'ye göre anlamlı olarak daha saptandı $(p<0,001)$.

Sonuç: Bu çalışma, ISS'nin GFR'si $\geq 60 \mathrm{~mL} /$ dak olan MM hastalarında tanıda önemli prognostik bilgi sağladığını göstermiştir. Bununla birlikte, tanı anında böbrek fonksiyon bozukluğu olan hastalarda B2-mikroglobulin, böbrek fonksiyon bozukluğundan ve tümör yükünden etkilenebileceğinden iyi bir prognostik gösterge olmayabilir.

Anahtar Sözcükler: Multipl myelom, B2-mikroglobulin, Uluslararası Evreleme Sistemi 


\section{Introduction}

The prognosis of multiple myeloma (MM) patients is highly heterogeneous. Tumor characteristics, microenvironment, and host factors such as age, renal insufficiency (RI), and comorbidities have been implicated as significant prognostic factors in MM patients. A reproducible and easily assessable prognostic system helps identify patients with poor prognosis and thus helps establish treatment plans for patients with poor prognosis [1]. Greipp et al. [2] developed the International Staging System (ISS) for MM patients. The ISS is based on B2-microglobulin and albumin, which are easily measured and examined in patients. The ISS has been validated and tested in MM patients treated with high-dose melphalan and autologous stem cell transplantation (ASCT) or conventional chemotherapy, and in patients treated with a new course of disease or upfront [3].

$\mathrm{Rl}$ is one of the major clinical manifestations in MM patients. It is considered as a poor prognostic factor, being associated with shorter survival or earlier death [4]. B2-microglobulin has a strong correlation with tumor burden, but serum B2-microglobulin does not only reflect MM. ISS staging increases in patients with elevated B2-microglobulin due to renal failure rather than tumor burden. Since 20\%-30\% of MM patients present with some degree of Rl, the elevation of B2-microglobulin due to renal dysfunction can compromise the prognostic value of the ISS [1]. The aim of this study is to determine the impact of patients' renal functions on the prognostic performance of the ISS. In addition, we aimed to evaluate the results of survival of patients with ISS stages and normal renal functions and those with ISS stages and abnormal renal functions with this study.

\section{Materials and Methods}

\section{Study Design, Patients, and Disease Characteristics}

This study was performed in a retrospective manner. Demographic data of the patients, ISS staging, and laboratory results were obtained from the hospital database. As a result of the application standards of the hospitals of our tertiary care center, it was recognized from the patient records that all of the studied patients had given informed consent at the time of hospitalization and before the administration of chemotherapy and other relevant diagnostic/therapeutic standards of care. A total of 204 consecutive patients with newly diagnosed MM who underwent ASCT after induction chemotherapy in our tertiary care center between the years of 2001 and 2018 were evaluated. Patients who were not eligible for ASCT were excluded from the study. Patients who received more than one ASCT were also excluded. Patients who received 4-6 courses of induction chemotherapy before ASCT were included in the study. This specific time period was chosen due to the routine use of VCD (bortezomib/cyclophosphamide/dexamethasone), VD (bortezomib/dexamethasone), and VAD (vincristine, doxorubicin and dexamethasone) as induction therapy. Response was determined according to the current International Myeloma Working Group response criteria [5].

\section{Definitions}

Renal function was evaluated with the estimated glomerular filtration rate, which was calculated using the modified Modification of Diet in Renal Disease (MDRD) formula, which uses age, sex, and serum creatinine level (GFR in $\mathrm{mL} / \mathrm{min} / 1.73 \mathrm{~m}^{2}$ ) [6]. The degree of Rl at the time of diagnosis was staged according to the National Kidney Foundation's Kidney Disease Outcomes Quality Initiative classification of chronic kidney disease (stage 1 with GFR of $\geq 90 \mathrm{~mL} / \mathrm{min}$; stage 2 with GFR of $60-89 \mathrm{~mL} / \mathrm{min}$; stage 3 with GFR of $30-59 \mathrm{~mL} / \mathrm{min}$; stage 4 with GFR of $15-29 \mathrm{~mL} / \mathrm{min}$; and stage 5 with GFR of $<15 \mathrm{~mL} / \mathrm{min}$ or undergoing dialysis) [7].

The ISS classification is based on serum albumin and serum B2-microglobulin at the time of initial diagnosis, before the initiation of anti-myeloma therapy [2]. Patients with serum albumin of $\geq 3.5 \mathrm{~g} / \mathrm{dL}$ and serum B2-microglobulin of $<3.5 \mathrm{mg} / \mathrm{L}$ were scored as stage I (ISS I), those with serum B2-microglobulin of $\geq 5.5 \mathrm{mg} / \mathrm{L}$ as stage III (ISS III), and those who did not fulfill the stage I or III criteria as stage II (ISS II).

In this study, we formed two groups: one that included patients with at least moderate renal dysfunction, namely patients with GFR of $\geq 60 \mathrm{~mL} / \mathrm{min}$, and another group that included patients with GFR of $<60 \mathrm{~mL} / \mathrm{min}$.

\section{Statistical Analysis}

Statistical analyses were performed using SPSS 25 (IBM Corp., Armonk, NY, USA). The variables were investigated using visual (histograms, probability plots) and analytical methods (Kolmogorov-Smirnov/Shapiro-Wilk test) to determine whether they were normally distributed or not. Statistical comparisons were made using chi-square tests for categorical data. The Student t-test for two independent samples was used for comparison of continuous numerical data. Survival analyses were performed using the Kaplan-Meier test. Multivariate analysis of predictors of survival was performed using the Cox regression test. Parameters with values of $p \leq 0.20$ in univariate tests were included in the multivariate analysis. Values of $p<0.05$ were considered to indicate statistical significance.

\section{Results}

\section{Patient Characteristics}

A total of 204 patients were enrolled in the study between 2001 and 2018. Patient characteristics are summarized in Table 1. There were $153(75 \%)$ MM patients who had GFR of $\geq 60 \mathrm{~mL} / \mathrm{min}$ and $51(25 \%) \mathrm{MM}$ patients who had GFR of 
$<60 \mathrm{~mL} / \mathrm{min}$ at the time of diagnosis. There were 124 (60.8\%) males and 80 (39.2\%) females with a median age of 58 (range: 35-76) years at the time of diagnosis. The numbers of patients classified with Eastern Cooperative Oncology Group performance status (ECOG PS) 0-1 and 2 were 148 (72.5\%) and 56 (27.5\%), respectively. There was no statistically significant difference between the two groups in terms of ECOG PS ( $p=0.27)$ [8]. No statistically significant difference was found between the groups in terms of age $(p=0.36)$ or sex $(p=0.74)$. There was a strong correlation between ISS stage and GFR. The ISS staging was higher in patients who had GFR of $<60 \mathrm{~mL} / \mathrm{min}$ than patients who had GFR of $\geq 60 \mathrm{~mL} / \mathrm{min}(\mathrm{p}<0.001)$. The distribution of GFR according to the ISS is depicted in Table 2. Patients with GFR of $<60 \mathrm{~mL} / \mathrm{min}$ were significantly more prevalent in the ISS III group than ISS I and II $(p<0.001)$. Serum hemoglobin levels were higher in patients who had
GFR of $\geq 60 \mathrm{~mL} / \mathrm{min}$ than patients who had GFR of $<60 \mathrm{~mL} / \mathrm{min}(\mathrm{p}=0.003)$. Serum calcium level $(p=0.01)$, B2-microglobulin $(p<0.001)$, and creatinine levels $(p<0.001)$ were statistically significant higher in patients who had GFR of $<60 \mathrm{~mL} / \mathrm{min}$ than patients who had GFR of $\geq 60 \mathrm{~mL} / \mathrm{min}(\mathrm{p}<0.001)$. Serum platelet counts $(p=0.27)$, lactate dehydrogenase levels $(p=0.80)$, and lytic bone lesions $(p=0.08)$ showed no statistically significant differences between the two groups. There was no statistically significant difference between the two groups in terms of MM types $(p=0.64)$, relapse rates $(p=0.82)$, and mortality rates $(p=0.87)$.

\section{Overall Outcomes}

The median follow-up period was 35.9 months (range: 4.2-206.4 months) for the entire group. The 5-year

\begin{tabular}{|c|c|c|c|}
\hline Parameters & GFR $\geq 60 \mathrm{~mL} / \mathrm{min}$ & GFR $<60 \mathrm{~mL} / \mathrm{min}$ & p \\
\hline n (\%) & $153(75 \%)$ & $51(25 \%)$ & \\
\hline Age (range) & $57(35-76)$ & $58(40-69)$ & 0.36 \\
\hline Sex, male/female (\%) & 92/61 (60.1\%/39.9\%) & $32 / 19(62.7 \% / 37.3 \%)$ & 0.74 \\
\hline ECOG PS & & & 0.27 \\
\hline $0-1(\%)$ & $114(74.5 \%)$ & 34 (66.7\%) & \\
\hline $2(\%)$ & 39 (25.5\%) & 17 (33.3\%) & \\
\hline ISS & & & $<0.001$ \\
\hline ISS I (\%) & $99(64.7 \%)$ & $6(11.8 \%)$ & \\
\hline ISS II (\%) & $45(29.4 \%)$ & $17(33.3 \%)$ & \\
\hline ISS III (\%) & $9(5.9 \%)$ & $28(54.9 \%)$ & \\
\hline Type of MM & & & 0.64 \\
\hline Ig G kappa (\%) & $57(37.3 \%)$ & $15(29.4 \%)$ & \\
\hline Ig G lambda (\%) & $27(17.6 \%)$ & $10(19.6 \%)$ & \\
\hline Ig A kappa (\%) & $23(15 \%)$ & $6(11.8 \%)$ & \\
\hline Ig A lambda (\%) & $11(7.2 \%)$ & $5(9.8 \%)$ & \\
\hline $\lg$ D lambda (\%) & $2(1.3 \%)$ & 0 & \\
\hline $\lg$ M kappa (\%) & $2(1.3 \%)$ & $1(2 \%)$ & \\
\hline Kappa light chain (\%) & $20(13.1 \%)$ & $6(11.8 \%)$ & \\
\hline Lambda light chain (\%) & $11(7.2 \%)$ & $8(15.7 \%)$ & \\
\hline Serum $\mathrm{Hb}$ level at diagnosis $(\mathrm{g} / \mathrm{dL})$ & $11.9(6.3-16.3)$ & $10.9(6.4-16.6)$ & 0.003 \\
\hline Serum PLT level at diagnosis $(/ \mathrm{nL})$ & $220(23-663)$ & 224 (94-514) & 0.27 \\
\hline Serum creatinine level at diagnosis $(\mathrm{mg} / \mathrm{dL})$ & $0.7(0.3-1.5)$ & $2(1-13.8)$ & $<0.001$ \\
\hline Serum calcium level at diagnosis (mmol/L) & $9.1(7.6-12.5)$ & $9.4(8-12.8)$ & 0.01 \\
\hline LDH $>$ UNL at diagnosis $(\%)$ & $99(64.7 \%)$ & $32(62.7 \%)$ & 0.80 \\
\hline B2-microglobulin level & $2.3(0.9-18.5)$ & $5.9(1.2-33.9)$ & $<0.001$ \\
\hline Lytic bone lesion (\%) & $75(49.0 \%)$ & $32(62.7 \%)$ & 0.08 \\
\hline Relapse rate (\%) & $43(28.1 \%)$ & $15(29.4 \%)$ & 0.85 \\
\hline Mortality rate (\%) & $28(18.3 \%)$ & $6(11.8 \%)$ & 0.27 \\
\hline 5 -year OS (\%) & $75 \%$ & $78 \%$ & 0.25 \\
\hline 5 -year DFS (\%) & $46 \%$ & $55 \%$ & 0.57 \\
\hline
\end{tabular}


overall survival (OS) for all patients was 77\% in MM patients staged as ISS I, 85\% in MM patients staged as ISS II, and 59\% in MM patients staged as ISS III $(p=0.36)$ The 5 -year diseasefree survival (DFS) rate for all patients was 48\% in MM patients staged as ISS I, 51\% in MM patients staged as ISS II, and 48\% in MM patients staged as ISS III ( $p=0.76)$ (Figure 1).

The 5-year OS for patients with GFR of $\geq 60 \mathrm{~mL} / \mathrm{min}$ was $75 \%$ in MM patients staged as ISS I, 86\% in MM patients staged as ISS II, and 0\% in MM patients staged as ISS III ( $p=0.002)$. The 5 -year DFS for patients with GFR of $\geq 60 \mathrm{~mL} / \mathrm{min}$ was $46 \%$ in MM patients staged as ISS I, 52\% in MM patients staged as ISS II, and 0\% in MM patients staged as ISS III ( $p=0.25)$ (Figure 2).

The 5-year OS for patients with GFR of $<60 \mathrm{~mL} / \mathrm{min}$ was $100 \%$ in MM patients staged as ISS I, 80\% in MM patients staged as ISS II, and $72 \%$ in MM patients staged as ISS III $(p=0.46)$. The 5 -year DFS for patients with GFR of $<60 \mathrm{~mL} / \mathrm{min}$ was $66 \%$ in MM patients staged as ISS I, 42\% in MM patients staged as ISS II, and 55\% in MM patients staged as ISS III ( $p=0.80)$ (Figure 3).

\section{Cox Regression Analysis}

Univariate and multivariate Cox regression analyses were performed for the factors that could affect OS and DFS. We evaluated Cox regression analysis in two different groups according to the patients' GFR values. In univariate analyses the factors that affected $O S$ were the age of the patients $(p=0.09)$, ISS staging (ISS I, II) $(p=0.17)$, and ECOG PS $(p=0.12)$ of the patients with GFR of $\geq 60 \mathrm{~mL} / \mathrm{min}$, as shown in Table 3 . Cox regression analysis revealed no parameters to predict OS. In univariate analyses, the factors that affected DFS were age of the patients $(p=0.09)$ and ECOG PS $(p=0.12)$ of the patients with $\mathrm{GFR}$ of $\geq 60 \mathrm{~mL} / \mathrm{min}$. Cox regression analysis revealed only age of the patients $(p=0.009)$ as being able to predict DFS.

In univariate analyses, the factors that affected OS were lytic bone lesions $(p=0.17)$ and ECOG PS $(p=0.02)$ of the patients with GFR of $<60 \mathrm{~mL} / \mathrm{min}$, as shown in Table 3. Cox regression analysis revealed ECOG PS and lytic bone lesions to predict OS. In univariate analyses, the factors that affected DFS were lytic bone lesions $(p=0.16)$ and ECOG PS $(p=0.01)$ of the patients with GFR of $<60 \mathrm{~mL} / \mathrm{min}$. Cox regression analysis revealed only ECOG PS of the patients $(p=0.006)$ as being able to predict DFS (Table 3).

\section{Discussion}

MM is characterized by heterogeneity in the clinical course of the disease and thus risk stratification is essential for prediction of prognosis. For developing a more clinically appropriate, objective, and applicable staging system for MM, the ISS was recommended [2]. Serum B2-microglobulin and serum albumin were evaluated as the most consistent and extensively feasible

\begin{tabular}{|c|c|c|c|c|}
\hline Parameters & ISS I & ISS II & ISS III & $\mathbf{p}$ \\
\hline GFR at diagnosis & n (\%) & n (\%) & n $(\%)$ & $<0.001$ \\
\hline$<60(\%)$ & $6(5.7 \%)$ & $17(27.4 \%)$ & $28(75.7 \%)$ & \\
\hline Serum creatinine level $(\mathrm{mg} / \mathrm{dL})$ at diagnosis & $0.7(0-3-1.7)$ & $0.8(0.3-5.6)$ & $1.9(0.6-13.8)$ & $<0.001$ \\
\hline
\end{tabular}
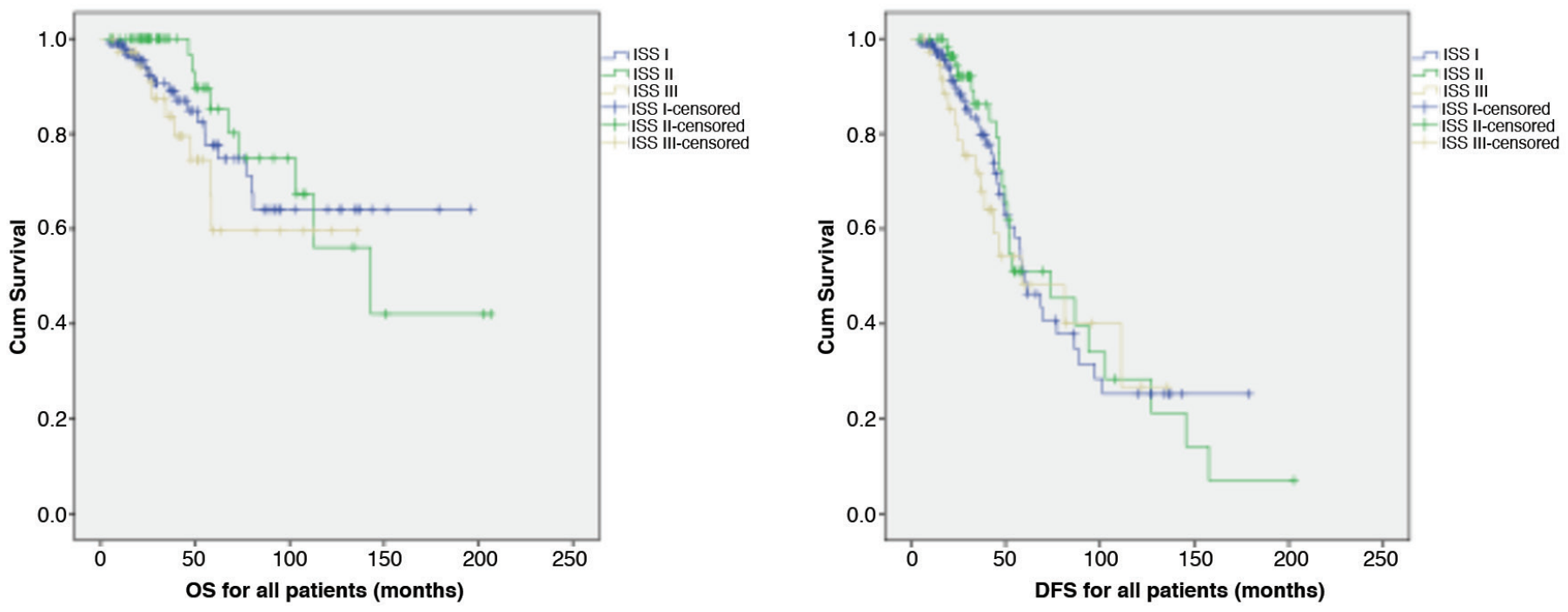

Figure 1. Overall survival (OS) $(p=0.36)$ and disease-free survival (DFS) ( $p=0.76)$ for all patients. 
prognostic factors among a number of statistically significant parameters correlated with survival outcomes [2]. The ISS is based on the measurement of serum albumin and B2-microglobulin levels. However, the cutoff levels have remained a matter of controversy because RI could elevate B2-microglobulin levels even in patients with low tumor burden. Therefore, the ISS cannot consistently provide a good estimate of tumor burden [9]. As a result, it may not accurately predict survival outcomes. In this study, our aim was to evaluate whether the staging of the ISS according to GFR would be effective in predicting the prognosis of patients and survival outcomes.

This study indicated that ISS staging is affected by the degree of GFR. Of the 204 patients we evaluated, GFR was less than $60 \mathrm{~mL} / \mathrm{min}$ at the time of diagnosis in 51 (25\%) patients. The B2-microglobulin levels were significantly higher in these patients than in the patients with GFR of $\geq 60 \mathrm{~mL} / \mathrm{min}$. OS and

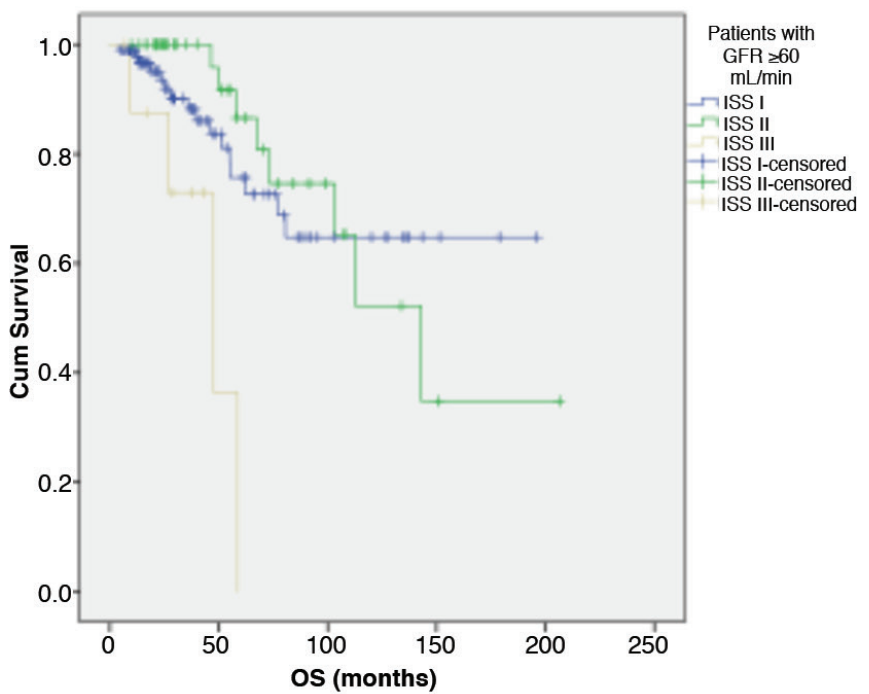

Figure 2. Overall survival (OS) ( $p=0.002)$ and disease-free survival (DFS) $(p=0.25)$ for patients with $G F R$ of $\geq 60 \mathrm{~mL} / \mathrm{min}$.
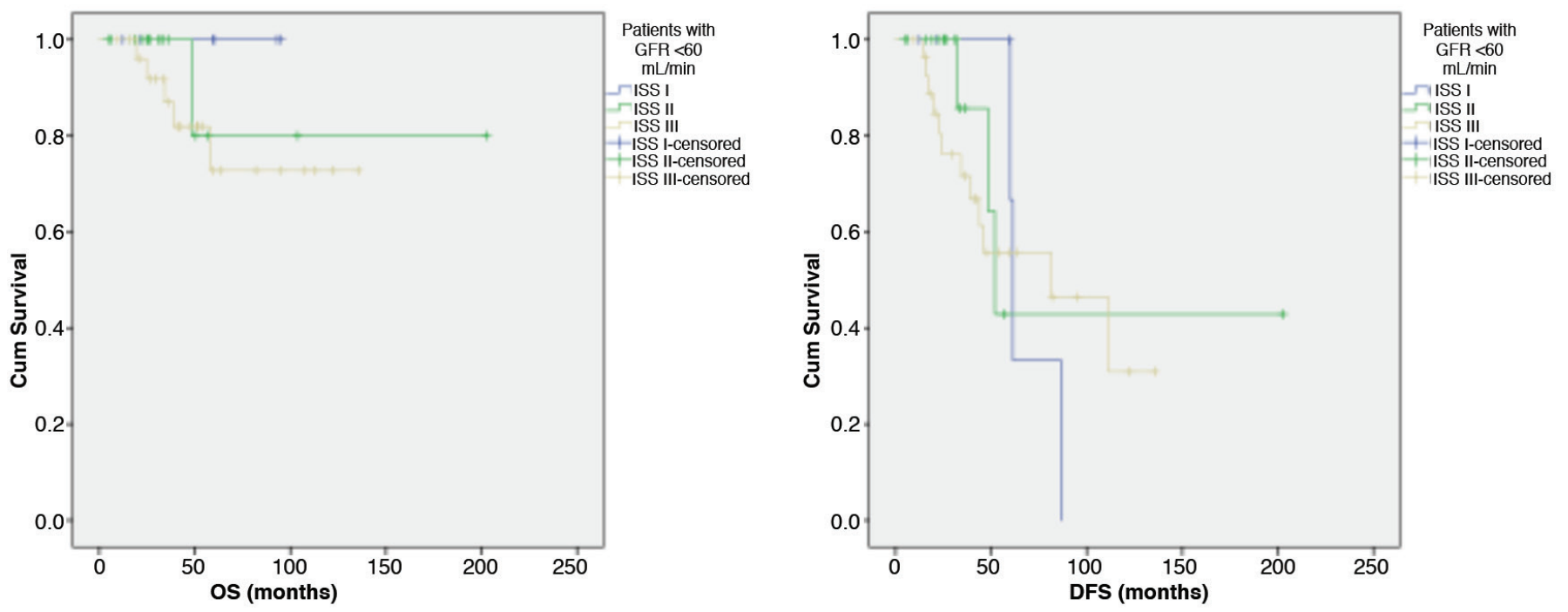

DFS were not significantly correlated with ISS for all patients. However, when we analyzed patients with GFR of $\geq 60 \mathrm{~mL} / \mathrm{min}$, OS was significantly higher in patients with ISS I and II staging than in patients with ISS III. DFS was not statistically significant in patients with GFR of $\geq 60$, but DFS was higher in patients with ISS I and II staging than in patients with ISS III. When we analyzed the patients with GFR of $<60$, there was no significant correlation between OS or DFS and ISS stages. The low patient number might have resulted in this lack of a correlation of OS and DFS with ISS. If the number of patients with GFR of $<60 \mathrm{~mL} / \mathrm{min}$ was higher, OS and DFS could have differed statistically. We found that particularly in patients with ISS III disease, which includes the majority of patients with RI, the degree of renal dysfunction as assessed by either GFR or serum creatinine does not have any prognostic impact on OS and DFS in either univariate or multivariate analysis. These results suggest that there may be no prognostic significance of ISS stage in

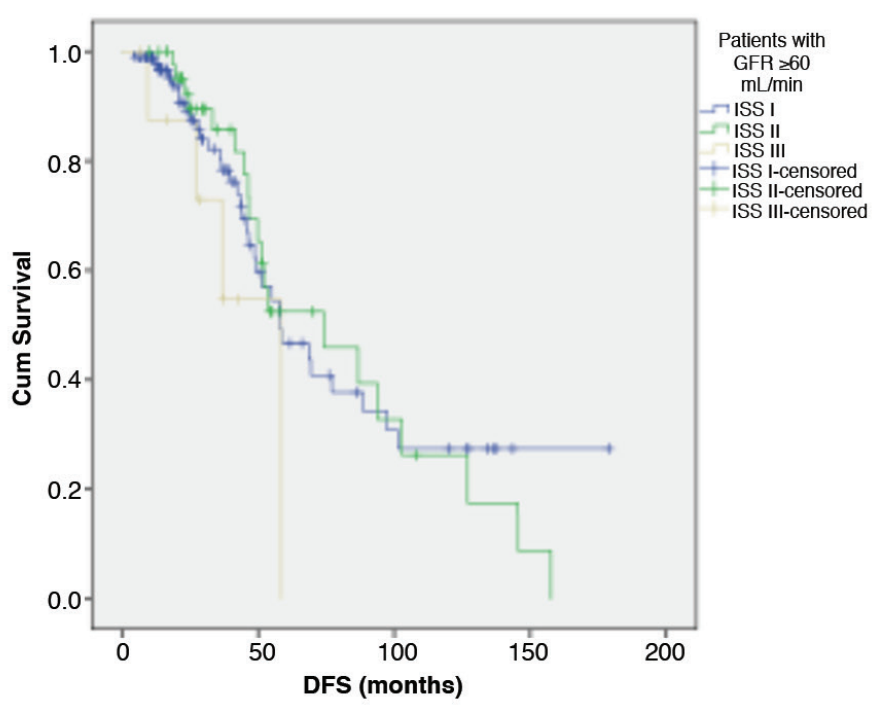

Figure 3. Overall survival (OS) $(p=0.46)$ and disease-free survival (DFS) $(p=0.80)$ for patients with GFR of $<60 \mathrm{~mL} / \mathrm{min}$. 
patients with renal failure at the time of diagnosis, because the level of B2-microglobulin due to renal failure will increase even if the tumor burden is low.

The GFR as estimated by the MDRD equation has not been developed to evaluate acute renal failure [6], which is present in many MM patients [10]. A more comprehensive evaluation, including data about renal function before the diagnosis of MM and the course of renal function over a period of time, would be necessary to assess MM-related acute renal failure [1]. However, such data are available only for a small fraction of patients. In this case, it was one of the limitations of our study. Another limitation is that the study was retrospective. Additionally, in this study, the prognostic significance of the ISS was evaluated according to the GFR only in newly diagnosed MM patients eligible for ASCT. Patients who were not eligible for ASCT were excluded from the study.

The incidence of $\mathrm{RI}$ in $\mathrm{MM}$ varies from series to series. One study showed that $21 \%$ of new patients with MM presented with renal failure as defined by serum creatinine of $\geq 2 \mathrm{mg} / \mathrm{dL}$ [11]. Alexanian et al. [12] showed that only 3\% of patients with low tumor burden presented with creatinine of $>2 \mathrm{mg} / \mathrm{dL}$ while $40 \%$ of patients with high tumor burden had creatinine of $>2 \mathrm{mg} / \mathrm{dL}$. Thus, the study showed that in patients with ISS III disease, which includes many patients with renal failure, elevated B2-microglobulin remains a strong surrogate of tumor burden, despite its increase due to RI [12]. The ISS has been used as an independent prognostic system in recent years, but it is unable to reflect the cytogenetic abnormalities of MM patients. Some new prognostic factors were found using fluorescent in situ hybridization (FISH), karyotypes, and serum free light chains $[13,14]$. A recent study from the IMWG combined the ISS, calcium, LDH, and FISH data to produce the Revised-ISS (R-ISS) [15]. In another study, the incidence of RI was 31\% in newly diagnosed patients with MM, and it was shown to be affected by renal response, treatment, and ISS staging [16]. Renal failure is a prognostic factor in MM patients, as it positively correlates with increased mortality [17]. Goswami et al. [18] have shown that existing MM staging systems (the ISS and Durie-Salmon staging) are not sufficient for distinguishing between risk groups. They reported that certain variables (recurrence after remission, number of regimens used before transplantation, response to induction chemotherapy, serum albumin level, pre-transplant M-protein level) are important factors in predicting OS and DFS. Another recent study showed that pretransplant induction therapy is an independent prognostic factor for DFS, while ISS stage and post-transplant complete response and very good partial response are independent prognostic factors for OS and DFS [19]. Besides all these, the widespread development, validation, and clinical use of molecular technologies such as FISH and next-generation sequencing have led to the identification of a number of prognostic and predictive biomarkers for DFS, OS, and treatment response $[20,21,22]$.

\begin{tabular}{|c|c|c|c|c|c|c|c|c|}
\hline \multirow[b]{3}{*}{ Parameters for OS } & \multicolumn{4}{|c|}{ Patients with GFR of $\geq 60 \mathrm{~mL} / \mathrm{min}$} & \multicolumn{4}{|c|}{ Patients with GFR of $<60 \mathrm{~mL} / \mathrm{min}$} \\
\hline & \multirow{2}{*}{$\begin{array}{l}\text { Univariate } \\
\text { analyses }\end{array}$} & \multicolumn{3}{|c|}{ Multivariate analyses } & \multirow{2}{*}{$\begin{array}{l}\begin{array}{l}\text { Univariate } \\
\text { analyses }\end{array} \\
\mathbf{p}\end{array}$} & \multicolumn{3}{|c|}{ Multivariate analyses } \\
\hline & & $\begin{array}{l}\text { Hazard } \\
\text { ratio }\end{array}$ & $\begin{array}{l}95 \% \text { confidence } \\
\text { interval }\end{array}$ & $\mathbf{p}$ & & $\begin{array}{l}\text { Hazard } \\
\text { ratio }\end{array}$ & $\begin{array}{l}\text { 95\% confidence } \\
\text { interval }\end{array}$ & $\mathbf{p}$ \\
\hline Age $(>58)$ & 0.09 & 0.482 & $0.219-1.061$ & 0.07 & 0.92 & & & \\
\hline ISS staging (I-II) & 0.17 & 1.426 & $0.754-2.696$ & 0.27 & 0.25 & & & \\
\hline Type of MM & 0.65 & & & & 0.96 & & & \\
\hline ECOG PS (0-1) & 0.12 & 1.742 & $0.788-3.848$ & 0.17 & 0.02 & 21.421 & $2.070-221.641$ & 0.01 \\
\hline LDH level (normal) & 0.34 & & & & 0.97 & & & \\
\hline Sex (male/female) & 0.96 & & & & 0.79 & & & \\
\hline ISS staging (I-II) & 0.38 & & & & 0.80 & & & \\
\hline Type of MM & 0.94 & & & & 0.41 & & & \\
\hline ECOG PS (0-1) & 0.18 & 1.566 & $0.891-2.752$ & 0.11 & 0.01 & 3.869 & $1.461-10.244$ & 0.006 \\
\hline LDH level (normal) & 0.59 & & & & 0.50 & & & \\
\hline Lytic bone lesions & 0.23 & & & & 0.16 & 2.737 & $0.911-8.225$ & 0.07 \\
\hline
\end{tabular}




\section{Conclusion}

This study showed that the ISS provides significant prognostic information in MM patients with GFR of $\geq 60 \mathrm{~mL} / \mathrm{min}$ at diagnosis. However, in patients with impaired renal function at the time of diagnosis, B2-microglobulin may not be a good prognostic indicator since it may be affected by renal dysfunction as well as tumor burden. The addition of other factors such as LDH, karyotyping, or FISH analysis may improve prognostic ability.

\section{Ethics}

Ethics Committee Approval: All of the ethical considerations were strictly followed in accordance with the 1964 Declaration of Helsinki. As standard care/action of the hospitals of the Hacettepe Medical School, it has been recognized from the patient records that all of the studied patients had given informed consent at the time of hospitalization and before the administration of chemotherapy and other relevant diagnostic/ therapeutic standards of care.

\section{Authorship Contributions}

Surgical and Medical Practices: R.Ç.; Concept: Y.B.; Design: H.D.; Data Collection or Processing: R.Ç.; Analysis or Interpretation: Y.B., H.G., N.S., 0.Ö.; Literature Search: I.C.H., S.A.; Writing: R.Ç.

Conflict of Interest: No conflict of interest was declared by the authors.

Financial Disclosure: The authors declared that this study received no financial support.

\section{References}

1. Dimopoulos MA, Kastritis E, Michalis E, Tsatalas C, Michael M, Pouli A, Kartasis Z, Delimpasi S, Gika D, Zomas A, Roussou M, Konstantopoulos K, Parcharidou A, Zervas K, Terpos E; Greek Myeloma Study Group. The International Scoring System (ISS) for multiple myeloma remains a robust prognostic tool independently of patients' renal function. Ann Oncol 2011;23:722-729.

2. Greipp PR, San Miguel J, Durie BG, Crowley JJ, Barlogie B, Bladé J, Boccadoro M, Child JA, Avet-Loiseau H, Kyle RA, Lahuerta JJ, Ludwig $H$, Morgan G, Powles R, Shimizu K, Shustik C, Sonneveld P, Tosi P, Turesson I, Westin J. International staging system for multiple myeloma. J Clin Oncol 2005;23:3412-3420.

3. Kastritis E, Zervas K, Symeonidis A, Terpos E, Delimbassi S, Anagnostopoulos N, Michali E, Zomas A, Katodritou E, Gika D, Pouli A, Christoulas D, Roussou $M$, Kartasis Z, Economopoulos T, Dimopoulos MA. Improved survival of patients with multiple myeloma after the introduction of novel agents and the applicability of the International Staging System (ISS): an analysis of the Greek Myeloma Study Group (GMSG). Leukemia 2009;23:1152-1157.

4. Augustson BM, Begum G, Dunn JA, Barth NJ, Davies F, Morgan G, Behrens J, Smith A, Child JA, Drayson MT. Early mortality after diagnosis of multiple myeloma: analysis of patients entered onto the United Kingdom Medical Research Council trials between 1980 and 2002-Medical Research Council Adult Leukaemia Working Party. J Clin Oncol 2005;23:9219-9226.

5. Kumar S, Paiva B, Anderson KC, Durie B, Landgren O, Moreau P, Munshi $N$, Lonial S, Bladé J, Mateos MV, Dimopoulos M, Kastritis E, Boccadoro M, Orlowski R, Goldschmidt H, Spencer A, Hou J, Chng WJ, Usmani SZ, Zamagni E, Shimizu K, Jagannath S, Johnsen HE, Terpos E, Reiman A, Kyle
RA, Sonneveld P, Richardson PG, McCarthy P, Ludwig H, Chen W, Cavo M, Harousseau JL, Lentzsch $S$, Hillengass J, Palumbo A, Orfao A, Rajkumar SV, Miguel JS, Avet-Loiseau H. International Myeloma Working Group consensus criteria for response and minimal residual disease assessment in multiple myeloma. Lancet Oncol 2016;17:e328-e46.

6. Levey AS, Bosch JP, Lewis JB, Greene T, Rogers N, Roth D. A more accurate method to estimate glomerular filtration rate from serum creatinine: a new prediction equation. Modification of Diet in Renal Disease Study Group. Ann Intern Med 1999;130:461-470.

7. National Kidney Foundation. K/DOOI clinical practice guidelines for chronic kidney disease: evaluation, classification, and stratification. Am J Kidney Dis 2002;39(2 Suppl 1):S1-266.

8. Oken MM, Creech RH, Tormey DC, Horton J, Davis TE, McFadden ET, Carbone PP. Toxicity and response criteria of the Eastern Cooperative Oncology Group. Am J Clin Oncol 1982;5:649-656.

9. Ooi MGM, de Mel S, Chng WJ. Risk stratification in multiple myeloma. Curr Hematol Malig Rep 2016;11:137-147.

10. Dimopoulos M, Kastritis $E_{1}$ Rosinol L, Blade J, Ludwig H. Pathogenesis and treatment of renal failure in multiple myeloma. Leukemia 2008;22:14851493.

11. Eleftherakis-Papaiakovou V, Anagnostopoulos A, Bamias A, Gika D, Symeonidis A, Pouli A, Anagnostopoulos N, Zervas K, Michali E, Kastritis E, Dimopoulos MA. Renal failure in multiple myeloma: incidence, correlations and prognostic significance. Blood 2006;108:5000.

12. Alexanian R, Barlogie B, Dixon D. Renal failure in multiple myeloma. Arch Intern Med 1990;150:1693-1695.

13. Mikhael JR, Dingli D, Roy $V$, Reeder CB, Buadi FK, Hayman SR, Dispenzieri A, Fonseca R, Sher T, Kyle RA, Lin Y, Russell SJ, Kumar S, Bergsagel PL, Zeldenrust SR, Leung $N$, Drake MT, Kapoor P, Ansell SM, Witzig TE, Lust JA, Dalton RJ, Gertz MA, Stewart AK, Rajkumar SV, Chanan-Khan A, Lacy MQ; Mayo Clinic. Management of newly diagnosed symptomatic multiple myeloma: updated Mayo Stratification of Myeloma and RiskAdapted Therapy (mSMART) consensus guidelines 2013. Mayo Clin Proc 2013:88:360-376.

14. Corso A, Galli M, Mangiacavalli S, Rossini F, Nozza A, Pascutto C, Montefusco V, Baldini L, Cafro AM, Crippa C, Cazzola M, Corradini P. Response-adjusted ISS (RaISS) is a simple and reliable prognostic scoring system for predicting progression-free survival in transplanted patients with multiple myeloma. Am J Hematol 2012;87:150-154.

15. Avet-Loiseau H, Durie BG, Cavo M, Attal M, Gutierrez N, Haessler J, Goldschmidt H, Hajek R, Lee JH, Sezer O, Barlogie B, Crowley J, Fonseca R, Testoni N, Ross F, Rajkumar SV, Sonneveld P, Lahuerta J, Moreau P, Morgan G; International Myeloma Working Group. Combining fluorescent in situ hybridization data with ISS staging improves risk assessment in myeloma: an International Myeloma Working Group collaborative project. Leukemia 2013:27:711-717.

16. Park S, Han B, Kim K, Kim SJ, Jang JH, Kim WS, Jung CW. Renal insufficiency in newly-diagnosed multiple myeloma: analysis according to International Myeloma Working Group consensus statement. Anticancer Res 2014;34:4299-4306.

17. Heher EC, Rennke HG, Laubach JP, Richardson PG. Kidney disease and multiple myeloma. Clin J Am Soc Nephrol 2013;8:2007-2017.

18. Goswami C, Poonia S, Sengupta D, Kumar L. Staging system to predict the risk of relapse in multiple myeloma patients undergoing autologous stem cell transplantation. Front Oncol 2019;9:633.

19. Zhang BL, Zhou J, Lin $Q D$, Liu $Y Z$, Zhang $Y L$, Gui RR, Song YP, Fang BJ. Retrospective analysis of the efficacy and influencing factors of autologous hematopoietic stem cell transplantation for multiple myeloma. Artif Organs 2019;43:1028-1034.

20. Pawlyn C, Davies FE. Toward personalized treatment in multiple myeloma based on molecular characteristics. Blood 2019;133:660-675. 
21. Shah V, Sherborne AL, Walker BA, Johnson DC, Boyle EM, Ellis S, Begum DB, Proszek PZ, Jones JR, Pawlyn C, Savola S, Jenner MW, Drayson MT, Owen RG, Houlston RS, Cairns DA, Gregory WM, Cook G, Davies FE, Jackson GH, Morgan GJ, Kaiser MF. Prediction of outcome in newly diagnosed myeloma: a meta-analysis of the molecular profiles of 1905 trial patients. Leukemia 2018;32:102-110.
22. Boyd KD, Ross FM, Chiecchio L, Dagrada GP, Konn ZJ, Tapper WJ, Walker BA, Wardell CP, Gregory WM, Szubert AJ, Bell SE, Child JA, Jackson GH, Davies FE, Morgan GJ; NCRI Haematology Oncology Studies Group. A novel prognostic model in myeloma based on co-segregating adverse FISH lesions and the ISS: analysis of patients treated in the MRC Myeloma IX trial. Leukemia 2012;26:349-355. 